\title{
Public-private Partnerships for Medicine Provision: an alternative to the combat to the covid-19 pandemic ${ }^{5}$
}

\author{
Jean Marcel Del Ponte Duarte ${ }^{1}$ \\ Rodrigo Nobre Fernandez ${ }^{1}$ \\ Rodrigo Vaz Silva ${ }^{2}$ \\ ${ }^{1}$ Federal University of Pelotas (PPGOM/UFPEL), Pelotas - RS, Brazil \\ ${ }^{2}$ University of Contestado, Mafra - SC, Brazil
}

This work aims to verify how the Public-private Partnership (PPP) contracts can be used as a tool for the policy makers to provide infrastructure in health services, specially seeking to fight the coronavirus pandemic, like the construction of hospitals and health centers, plus research and development of vaccines and medicine. An analysis of PPP cases already currently working in Brazil was conducted, based on an empiric literature. The PPPs arise as a feasible alternative of investments in this sector, particularly in a fragile moment of public accounts, in addition to the need of healthcare improvements throughout the country. Besides being more efficient, this kind of contract, in a short term, also attenuates the pressure on the public accounts since it is financed by private investments.

Key words: Public-private partnership, Medicines, Hospitals, Coronavirus.

\section{Parcerias público-privadas para a provisão de medicamentos: uma alternativa para o combate da pandemia do covid-19}

O presente trabalho tem como objetivo verificar como os contratos de Parcerias Público Privadas (PPP) podem funcionar como ferramentas de política pública para a provisão de infraestrutura de serviços de saúde, em especial visando o combate à pandemia do coronavírus, como a construção de hospitais e postos de saúde, além da pesquisa e desenvolvimento de vacinas e medicamentos. Foi feita uma análise de casos de PPPs já vigentes no Brasil, com base empírica na literatura. As PPPs surgem como uma alternativa viável de investimento nesse setor, principalmente em um momento frágil de contas públicas,

\footnotetext{
${ }^{5}$ DOI: https://doi.org/10.21874/rsp.v71i0.4972

ISSN: $0034-9240$ | E-ISSN: 2357-8017
}

\section{(a) (1) (2)}

Submitted: August 16, 2020. Published: August 20, 2020.

REVISTA Do SERVIÇo PúBlico | Brasília 71 (special): 91 - 110 set. 2020 
somado à urgência de melhorias na área da saúde. Além de serem mais eficientes, essa modalidade de contrato, no curto prazo, também alivia as contas públicas ao contar com investimento privado.

Palavras Chave: Parcerias Público-Privadas, Medicamentos, Hospitais, Coronavírus.

\section{Asociaciones público-privadas para la provisión de medicamentos: una alternativa al combate a la pandemia del covid-19}

El presente trabajo tiene como objetivo verificar cómo los contratos de Asociaciones PúblicoPrivadas (APP) pueden funcionar como herramientas de política pública para la provisión de infraestructura de servicios de salud, especialmente dirigidos a combatir la pandemia de Coronavirus, como a la construcción de hospitales y puestos de salud, así como a la investigación y al desarrollo de vacunas y medicamentos. Se realizó un análisis de casos de APP ya vigentes en Brasil, con base empírica en la literatura. Las APP aparecen como una alternativa viable de inversión en este sector, principalmente en un momento de fragilidad de las cuentas públicas, sumado a la urgencia de mejorías en el área de salud. Además de ser más eficiente, este tipo de contrato, al corto plazo, también alivia las cuentas públicas al depender de la inversión privada.

Palabras Clave: Asociación público-privada, Medicamentos, Hospitales, Coronavirus. 


\section{Introduction}

In early March of this year, the World Health Organization (WHO) classified the Coronavirus (COVID-19) disease outbreak as a pandemic which, until August 14 of 2020, has killed over 700 thousand of people worldwide. Controlling the spread of this disease appeared to be one of the most challenging economic slumps faced by the mankind in the last centuries.

The virus, known as SAR-COV-2, originated in China, spread fast worldwide, causing numerous deaths and an incalculable economic impact. All in all, governments tried to implement a set of policy measures focusing on fighting the spread of the virus and then being able to provide a minimum appropriate level of healthcare assistance to the people that really needed to use these services.

One of these policy measures defines that only business that are strictly considered essential may work, such as gas stations, markets, supermarkets and pharmacies. Moreover, the use of masks and social distancing is recommended to restrain the spread of the new disease. In this sense, restrictive measures may be important to achieve that goal (EICHEINBAUM et al., 2020; ALVAREZ et al., 2020; FARBOODI et al., 2020).

Although these measures aim to reduce the virus spread, there is no solid empirical evidence that they are effective (FONG et al., 2020; FANG et al., 2020). In the international literature, Friedson et al. (2020) and Bron et al. (2020) used the synthetic control method to assess these restrictive measures, in the United States of America and in Sweden, respectively. Besides these two studies, the work from Dave et al. (2020), Di Porto et al. (2020), Fang et al. (2020) and Gupta et al. (2020) employ the differences in differences method to analyze if government interventions may reduce the number of hospitalizations and deaths caused by the Covid-19, even though the results are contrasting.

In the Brazilian case, Oliveira et al. (2020) apply the differences in differences method, estimating that the economic costs of intensifying the social isolation were about $\mathrm{R} \$ 844$ thousand a day, while the benefits in terms of the reduction of cases and deaths from Covid-19 were not statistically significant. Utilizing a dynamic panel approach, Oliveira (2020) estimates that there would be a loss of approximately $\mathrm{R} \$ 43,36$ billion in sales and around $\mathrm{R} \$ 1,56$ billion in tax collection in the first 27 days of restrictive measures.

Inside this context of uncertainty, which tools can policy makers use to effectively guide the fight against the disease? In a productive way, the federal government, as well as some state governmental research institutes, have been developing partnerships with the private sector in order to produce vaccines and medicine to fight against the coronavirus. Plus, there are some 
legal instruments that may be used, such as the provisional measure 926 (PM), that reduced the bureaucracy for bidding contracts during the pandemic. In August of 2020, this PM has turned into law number 14.035.

Under this perspective, a feasible alternative already implemented around the world to provide healthcare services are Public-Private Partnerships (PPP). According to the Brazilian law 11.079 from 2004, a PPP is an administrative contract of concession, which can be sponsored or administrative.

A quite common argument from those who defend the use of PPP contracts is that, since they utilize private sector resources, the provision of infrastructure services to the population is not limited by the constrained public budget, as can be seen at Hart et al. (1997), Hart (2003), Bennett and lossa (2006), Martimort and Pouyet (2008), Engel et al. (2009), Barros and Giralt (2009), lossa and Martimort (2012), Nóbrega (2012), Nose (2017), Buso et al. (2017), lossa and Saussier (2018). Thus, the use of this contract model would allow an amplification of public services in fundamental areas, while removing the necessity for raising public expenditures in the short term.

But how are PPPs being affected by the new coronavirus and how should public parties react to it? The World Bank stresses that is undoubtedly important to have a healthy cooperation with the private sector in order to mobilize its financing and expertise for infrastructure development in general. The short-term impacts are, as expected, revenue losses for PPPs as well as delays in construction schedules, since logistics and labor are heavily affected. In the medium term, impacts in contracts in all stages are expected, whether it is through operations, seeking financial support or constructions currently underway. Capital injection, renegotiation and regulatory flexibility are some measures that can mitigate these impacts. The long-term impacts will depend on how long the pandemic lasts, and the focus will get back to achieving more sustainable and resilient infrastructure PPPs.

In the healthcare context, there is previous experience in using this contractual modality to the construction and the provision of hospital services. According to Taylor and Blair (2002), La Forgia and Harding (2009), Barros and Giralt (2009), the main factor of this type of contract is a guarantee of the service quality that will be offered. When talking about provisioning of vaccines and medicine, Brown (2008), Bagley and Tyarno (2014) highlight the use of PPPs for developing therapies and medicine for the treatment of infectious diseases.

According to Brown (2008), one of these partnerships is The Accelerated Access Initiative, which aims was created to promote access to therapies for people with HIV. This partnership consists in five organizations from the United Nation and six pharmaceutics companies. Another 
example of PPP in this sector is the Diflucan Partnership, which was released in December 2000 by the pharmaceutical company Pfizer, one of the biggest in the world in this sector, consisting of a donation program of an antifungal medicine for the treatment of common infections in HIV cases. The program also helps to train health professionals in fighting infectious diseases and has been placed in over 42 developing countries.

This way, this work focused mainly on verifying how contracts in Public-Private Partnerships can be used as a tool for policy makers to provide healthcare service infrastructure, especially for fighting the coronavirus pandemic, as well as the construction of new hospitals and development of vaccines and medicines for mass distribution.

To accomplish this task, this work is organized as follows: a brief consideration of laws regarding PPPs in the Brazilian context is made; then we review the literature about these contracts in the health scope; a discussion about the main possibilities that this contract modality may bring to providing new medicine and building new hospitals is made subsequently; finally, we present the concluding remarks.

\section{Some considerations about the PPPs}

First, it is necessary to make a few considerations about the traditional concessions governed by law 8.987 and the specials concessions (PPP) regulated by the law 11.079. The first is used as a model for the administrative contracts pass the provision of a certain service to a private firm.

According to Bandeira de Mello (2008), the traditional concession contract/model is the legal institute by which the State designed the public service provision to a third party that accepted to provide the service at their own risk and that the public party has the majority control of the contractual clauses.

This way, according to Brazilian legal guidelines, a PPP contract could be defined as the one that: i) has a value equal to or above ten million reais; ii) the period of service provision will not be less than five years or over thirty-five years; iii) aims to provide more than one service, for example, the construction and the operation of a facility.

From here, the possibilities of contract through public-private partnerships are divided into two modalities: sponsored or administrative. In the first one, the private party can be remunerated by receiving a fare collected from the users, as well as receiving financing from the public sector itself. A quite common example of this type is a road under the responsibility of a firm (concessionary) via PPP. 
In the administrative type, the private party provides the Public Administration a predetermined direct or indirect service. A possible contract in this modality is the construction and operation of a hospital. The patients (citizens) would be the direct users of the service and the administration would fit in the indirect use and pay for the service.

Within this context some previous limitations should be emphasized as the federal, state and city governments must accomplish contracts in this form. The federal government can only hire PPPs when the sum of all continuous expenditures of contracts in this modality do not exceed, in the past year, $1 \%$ of the net revenue of the exercise, and also the annual expenditures of the current contracts in the next 10 years do not exceed $1 \%$ of the net income projected for the respective projects.

Besides that, this public party can only guarantee or perform voluntary transference to states, federal district and cities if the sum of all their continued expenditures from the set of partnerships already hired by these parties did not exceed, in the past year, $5 \%$ of the current net revenue or if the annual expenditures of the current contracts in the next 10 years do not exceed $5 \%$ of the projected net revenue for the respective exercises.

A procedure prior to signature of a PPP contract is the constitution of a Specific Purpose Society (SPS), which seeks to promote the development of the proposed project by the contractual arrangement. The SPS can have the form of an open company and should comply with the international corporative government standards. However, the public administration cannot be the biggest voting holder in this organization.

According to the tenth article of law 11.079, the hiring of a PPP should be preceded by the authorization of a competent authority and must be reasoned by a technical study that shows the socioeconomic justifications for hiring by this contractual arrangement.

The sixth chapter of law 11.079 has provisions applicable to the Federal Union, since article 14 specifies that the Federal Entity Institute, which is a managing body with duties, among others, to define the priority services for the execution in the PPP regime and to regulate the procedures for honoring and execution of these contracts. This article was complemented by the Decree 5.385 from 2005, which instituted the Manager Committee of Public-Private Partnership in the federal scope; however, the Decree 9.784 from 2019 revoked this legislation and, currently, there is no regulation on this subject.

Another important mechanism is the Fundo Garantidor de Parcerias Público-Privadas (FGP), Guarantee PPP fund, which has the purpose to guarantee the pecuniary obligation assumed by public federal (state and municipal)). 
In short, another key feature that differentiates PPPs from conventional concession frameworks are risk sharing between the public and the private parties. As stated before, the special concessions have legal mechanisms that aim to guarantee that this mutual risk is minimized. The fiscal guidelines, the demand for viability projects and the supervision by the regulatory agencies formed by members of the State may be important tools for the risk reduction related to this contractual modality.

\section{PPPs and the provision of healthcare services}

There are many factors related to the quality of the healthcare services. In his classic work, Arrow (1963) highlight two main points: the infrastructure provided to patients and the doctors' ability to prescribe the best treatment. The high prices for the provision of these services is related to the high costs of empowering and forming professionals in the health science area. Considering that economic agents consider the provision of these services to be an important factor to their welfare level, governmental investments in infrastructure and capacitation of qualified professionals are welcome by the population.

In relation to these investments, Hart et al. (1997) developed a theoretical model that seeks to identify which conditions the government should be responsible for providing the service or alternatively when it can be transferred to the private sector. The authors' arguments suggest that the service provision when done by the government is stable when the cost reduction have great effects in the project quality, and in situations when the quality innovation is not relevant. On the other hand, privatization is preferable when cost reduction can be controlled by a competitive contract or when the innovation process can improve quality characteristics of the project. The healthcare sector suffers enormous damage due to cost reductions coming from the private parties and historically the hospitals concession contracts have been realized in the contractual form costplus ${ }^{46}$.

With the intention of evaluating if the property of the assets should be public or if the public party should only be responsible for providing the service, Bentz et al. (2001) compared two models of providing services, the conventional model or a consortium of private financing. The main factor that guides the government choice is the service delivery costs, since, if the costs are low, the government will strictly prefer to hire the final service instead of buying the asset. The problem of building a new facility is the information asymmetry. Even in complete contracts, the

\footnotetext{
${ }^{46}$ This kind of contract allows a private firm to be refunded for its costs, which are bound until a certain level, plus an additional payment that allows the firm to have a profit margin.
} 
new facility design might show some problems during the construction and, in this case, the firm that already provides the service may already know how to fix the problem, in addition to knowing its costs (if it's high or low), while the government does not have this information clearly. Thus, the government chooses to pay for the service if the building and delivering costs are low.

In an analysis more focused on the operational methods, Campos et al. (2011) investigate articles in the PPP literature for the health sector, seeking to understand the fundamental elements of the partnership process. In the developing stage, the most common subjects were win-win agreements, synergy of expertise, stakeholder engagement, local health capacity and infrastructure and the public and private sectors' perception regarding each other. In the development stage, communication, knowledge exchange, participatory management and organizational skills were the most common topics. It is important that the law helps keep these important pillars in order to receive the most efficiency from PPP contracts.

This way, governments should use the private sector's ability to finance, build or provide hospital services only when the efficiency level of the private partner is superior to the government's (BETTIGNIES AND ROSS, 2004). According to Mckee et al. (2006) the use of PPPs in hospitals made sure the projects were realized within the deadline specified in the contract, and also that the deal was within the expected budget. However, these efficiency improvements may cause costs related to the project quality. In this sense, Taylor and Blair (2002) say that mechanisms such as independent regulatory agencies are necessary to guarantee that the rules specified in the contract are being respected.

In the incomplete contracts scope, Hart (2003) develops a PPP model where the public entity is the owner of the asset after the project conclusion and that there are two options: hiring a third party to build and operate the project, or hiring two different companies. The author evaluates the PPP as a good alternative when service quality can be specified in the initial contract but building quality cannot. The principal example would be prisons and hospitals.

Under another point of view, Bennett and lossa (2006) point out that PPPs worked quite well for roads and prisons, causing cost reductions, bringing new design and administrative innovations, but this process did not show the same returns for schools and hospitals. PPP projects for hospitals demand investments in high quality materials and equipment, which raises the building and operational costs, and creates a need for training health area professionals, which in the short term may cause maintenance costs to raise. In this situation, signing unbundled contracts is a better alternative, according to the authors, who support that at the end of the PPP contract, the asset should be owned by the public entity in the case of hospitals, prisons and schools. 
As for the government's budget perspective, Maskin and Tirole (2008) report that the bundling type will not always induce the responsible firms to internalize operational cost reductions for the building and operating process. The bundling may lead to an efficiency loss because the builder is not necessarily the best operator. Moreover, bundling may encourage choices that induce the reduction of future costs at the expense of service quality or because of a collusion between the operator and their regulator, that together might manipulate the project in their favor.

The analysis from lossa and Martimort (2009) stress that the efficiency gain brought by the PPPs arrangements may be superior to the governmental traditional contract forms. However, PPPs might be inappropriate in some cases, as schools and elderly care facilities. That is because the quality of service is determined by the investment in capital human or in IT services (Information Technology) where the demand changes quickly over time. In the case of hospitals, the asset property may return to the public entity after the end of the contract, even though the private party can still provide the service.

Talking about the PPP contractual model for hospitals, Barros and Giralt (2009) point out that it is necessary to detail quite well the project to encourage the firm competition process. However, the public entity might not be as efficient as the private party to define and then supervise the expected quality in the hospital service. If quality measures are not well defined in the contract process, then the innovations brought by the private sector may get lost.

Another important point is the evaluation by Balduzzi (2011) who extends Hart's model (2003), analyzing the role of workforce on PPPs. According to the author, the public provision is the best pick when the employer and worker efforts are complementary and relevant. In general, services like healthcare demand a high level of investment from the private company and should be kept with the public sector. Otherwise, PPPs are the best choice.

A key issue in the opinion of La Forgia and Harding (2009) and the Asian Development Bank (2013) is the supervision of a hospital PPP contract. Therefore, the contract should contain measurable goals, procedures for quality measure and a responsible organ for making reports. The responsible unit should develop a procedures manual for performance verification in relation to the contract and to answer to any contract deviations.

In addition to providing hospital services, PPPs can also be utilized to connect private and public interests related to research and development in the medicine production area (VRUEH AND CROMMELIN, 2017). In general, there are 2 main types of PPPs that stimulate R\&D in the pharmaceutics area: i) The product developing PPP, which aims to develop medicine, vaccines, etc; ii) The precompetitive PPP, where both parts contribute to improve mainly infrastructure, in an effort combination between the private and public parts. 
The pharmaceutics industry, like any other, needs incentives to make firms keep investing in research and development, and to create new medicine and vaccines. Insurance coverage policies play a crucial role in this matter, since they can cause significative changes in the firms' investments, depending on the way they are applied. A smaller coverage from insurance plans might cause firms to invest less in R\&D (AGHA, KIM AND LI, 2020)

Peculiarly for that industry, a contract in the PPP mode serves as a link between new scientific discoveries and the final product that goes to the consumer. As stated by Wheeler and Berkley (2001), the majority of these partnerships includes the following stages: focus on a specific disease; receive funding from the public and philanthropic sectors; seek in-kind contributions from the industry through project partnerships; fund projects that involve for-profit partners, besides giving importance to R\&D investments and to intellectual property rights. The biotechnology companies and academics collaborate with pharmaceutical companies to define which discoveries have a more attractive technical and commercial potential.

Some diseases have fewer incentives for investments in R\&D, since they do not reach a vast number of patients, or they exist mostly in developing countries, where the population has limited financial resources and cannot access vaccines and medicines. In addition to that, the regulations in these countries may not be welcome for the innovation market for new drugs. PPPs can be a way to stimulate R\&D in this sector, decreasing costs and risks for both involved parties, private and public (NWAKA AND RIDLEY, 2003). The government system is also important, in view of the fact that the political debate translates how important subjects such as intellectual property rights are treated in each country, as well as innovation and access to essential medicine. Thus, it is important to keep these questions crystal clear and also guarantee good project management, in order to obtain beneficial agreements to both parts.

At the same time, only patent protection itself does not secure a bigger investment in R\&D for diseases with small market potential in rich countries (KYLE AND MCGAHAN, 2012). Apart from that, if there is market potential in developed countries, treatments and medicines developed may also benefit poor countries.

\section{Discussion}

The majority of the PPP literature says that this kind of contract may be efficient in extending public service offerings in fundamental areas, taking into consideration increasing budget constraints (AKITOBY, et al., 2006; ENGEL et al., 2013; BUSO et al., 2017). This contractual modality is a good opportunity for Brazil, which is facing a tight public budget, even 
causing the country to pass a constitutional amendment law (n. 95) limiting the level of government expenditures for twenty years.

To fight the coronavirus pandemic, PPPs can be used to provide medicine and health infrastructure, as building new hospitals and health centers. However, it is important to point out that according to the legal aspects of this form of agreement, it cannot be used to buy vaccines, for example, but for research and development of these new medicines.

In pecuniary terms, the PPP contract would fit quite well for medicine development. According to the Statistical Yearbook of the Pharmaceutical Market Design by Agência Nacional de Vigilância Sanitária (ANVISA) ${ }^{47}$ from 2018, this market involved more than R 76 billion in this year.

Another important point is the time horizon scheduled for this contract. However, the activities related to research and development of medicine and vaccines usually are not developed in short periods of time. Even though this can be a negative due to the urgency in the need for a vaccine as in the case of the coronavirus pandemic, the contract can still be valid beyond that. As for the service provision, the research, development and commercialization of pharmaceuticals also fits in the basic definitions of PPPs based on the Brazilian law.

Within that scope, it is worth stressing that the national experience with that contractual arrangement is new. According to information from Radar PPP ${ }^{48}$, a leader in following this contractual modality in Brazil, the country ended the year of 2018 with 120 contracts in the PPP type, with only three related to healthcare.

The first PPP contract signed in Brazil was in May of 2010, the PPP for the Hospital do Subúrbio from Bahia state, executed between Prodal Saúde S.A. and Secretaria do Estado da Bahia, seeking the administration of Unidade Hospitalar da Bahia. The concession has a 10-year term and a value of over $\mathrm{R} \$ 1$ billion. As a result of the efficiency gain from the administration and financial and technological innovation, the hospital has received a prize given to the ten best partnership projects in Latin America and Caribbean from the World Bank in 2013.

The second hospital from this type of PPP contract is the Hospital Metropolitano de Belo Horizonte, which was signed in March of 2013, between Novo Metropolitano S.A. and Secretaria Municipal de Saúde do Município de Belo Horizonte, to the realization of services and engineering works and administration of the hospital. The concession has a 20 -year term and roughly the same value as the first one. The most recent one is the Hospital da Zona Norte, executed between Zona Norte Engenharia, Manutenção e Gestão de Serviços S.A. and Secretaria de Saúde do Estado

\footnotetext{
${ }^{47}$ The Brazilian Health Surveillance Organ.

${ }^{48}$ https://www.radarppp.com/
} 
do Amazonas, in concession for the construction, equipment supply and non-assistance service maintenance and administration to the Hospital da Zona Norte de Manaus.

As stated in the previous section, PPP agreements are an alternative to the government provision of necessary medicine, when the government has interest in investigating and providing solutions to a certain disease, through research and development. It is possible to find an interaction that is effective between public entities (researchers in general, health entity, etc) and private companies with the intention that both share the same final objective of providing treatments or medicines for that disease.

PPPs for the health area cannot be used for purchasing products, only for the development of research aiming to provide vaccines. For that, there are productive developing partnerships, which are partnerships between two or more public institutions, or between public and private institutions, that seek to promote national public production of medicine and products for healthcare considered essential for the Sistema Único de Saúde (SUS), the Brazilian national healthcare system, through a boost to the industrial sector in Brazil. The main purpose is to promote the national development of medicine and health products that are currently imported or that represent a high cost for SUS, therefore seeking to reduce the purchase costs of these products. However, for a medium-term objective, when talking about the provision of hospitals, PPPs projects are more appropriate.

On the other hand, all the risks involved in the project, are shared between the parties, like failing to produce a vaccine. Also, the project making process usually takes around two years (MORAES AND REYES, 2017). In pandemic cases, such as right now, time is a quite valuable resource and this process should be done quickly, even though it is a rigorous process which demands attention to include everything that is necessary to encourage and ensure all the parties involved in the contract.

A feasible solution for reducing the project plan creation time is PM 926 which was converted into law 14.035, which seeks to facilitate the procedures on the acquisition of goods, services and work hiring and inputs intended to fight the coronavirus pandemic. These are exceptional measures for fighting the current situation of emergency in the country.

In addition, the federal government also has as an alternative for buying medicine the Product Developing Partnerships (PDP) that intend to increase the buying of medicine and healthcare products for the SUS. However, this proposal also aims to strengthen the national industry for the costs reduction for providing new drugs for the healthcare system. It is also included in the PDP, the innovation and development of new technologies helpful to the sector. 
An advantage of the PPPs have over PDPs is the flexibility of the service provision that the first one allows. Even though it is not possible to exclusively buy medicine, the possibility of combining several service provisions is a benefit from the special concession. However, the PPP contracts tend to be complex and that is why the period from the expression of interest to the beginning of the project is reasonably high, which is a barrier during the actual crisis moment. That way, it is necessary to minimize the bureaucracy what about contracts between public and private parties.

However, PPPs can be seen as a long-term loan, where the government receives financial investments from private parties, but give up on providing the service that might be profitable. In other words, the government is investing an opportunity in the private sector, trading off a potential income for a more efficient service. In this sense the point Bettignies and Ross (2004) make is especially important when they say the government should only use the private sector in contracts if their effectiveness is higher, since that, on average, PPP contracts tend to be more expensive than conventional concession contracts (MORAES AND REYES, 2017).

A different approach, even though still related to healthcare, is the Covid Radar ${ }^{49}$, which is a cooperation between over 40 companies and organizations, sharing data and combining efforts to face the coronavirus challenges in Brazil. It is possible to check real time information about coronavirus cases in every state and also a tool to connect people from all over the country, where is possible to offer or demand a specific product or service, as food, equipment, inputs, general services. Even though there is not a contract between the parties, it is still a public-private partnership intending to help those in need during this pandemic.

\section{Concluding Remarks}

This work intended to verify how PPP contracts may be used as a public policy mechanism for providing infrastructure in healthcare services, especially while fighting the coronavirus pandemic, where fast solutions are needed in order to contain the virus spread, treating already affected people, building new hospitals and for the research and development of new vaccines and medicine for mass distribution.

To accomplish this task, the PPP laws in the Brazilian context were considered, followed by a literature review of works that included these contracts especially in the health and

\footnotetext{
${ }^{49}$ https://www.covidradar.org.br/
} 
pharmaceutics areas, and then a discussion on how these contractual agreements could be applied in Brazil.

When fighting pandemics, the PPPs can be a valuable ally to promote the research and development of new vaccines and medicines for diseases as in the actual case of coronavirus. Considering that it is a viral infection, as in the H1N1 case, where the virus spreads quickly, the P\&D of these products should be done constantly, to make it easy to have an answer for that situation and to accomplish the objectives quickly.

The PPP contracts are not simple, since they can be related to a vast variety of services within each sector, for example, in the health scope, the building of hospitals and health centers, the provision of medical services, the management and administration of hospitals, etc. Plus, the contract should meet several requirements to guarantee that the partnership is effective, among them ensuring that both parties have the same final objective and engage to achieve it. Also, independent regulatory agencies should be created to ensure that both parties carry out the contract and respect the rules. The sophistication of these contracts to the pharmaceutical and health fields is a topic with high potential to be expanded in future works. There is a wide range of contracts that can be signed through PPPs to improve the basic Brazilian infrastructure.

\section{References}

AGÊNCIA NACIONAL DE VIGILÂNCIA SANITÁRIA. Anuário Estatístico do Mercado Farmacêutico. Available on <http://portal.anvisa.gov.br/documents/374947/3413536/Anu\%C3\%A1rio+Estat\%C3\%ADstico+d o+Mercado+Farmac\%C3\%AAutico+-+2018/c24aacbf-4d0c-46a7-bb86-b92c170c83e1>.

Accessed on $08 / 10 / 2020$

AGHA, L.; KIM, S.; LI, D. Insurance Design and Pharmaceutical Innovation. Working Paper, National Bureau of Economic Research, 2020.

AKITOBY, B.; HEMMING, R.; SCHWARTZ, G. Public Investment and Public-Private Partnership. International Monetary Fund Economic Issue, n. 40, 2006.

ALVAREZ, F. E.; ARGENTE, D.; LIPPI, F. A Simple Planning Problem for COVID-19 Lockdown. Working Paper, National Bureau of Economic Research, 2020.

ARROW, K. J. Uncertainty and the Welfare Economics of Medical Care. The American Economic Review, v. 53, n. 5, p. 941-973, 1963. 
BAGLEY, C. E.; TVARNO, C. D. Pharmaceutical Public-Private Partnerships: Moving from The Bench to The Bedside. Harvard Business Law Review, v. 4, p. 373-401, 2014.

BALDUZZI, P. Models of Public-Private Partnerships for the Provision of Goods. Economics \& Politics, v. 23, n. 2, p. 271-296, 2011.

BALDWIN, R.; DI MAURO, B. Economics in the Time of COVID-19. CEPR Press VoxEU.org eBook, 2020.

BANCO DE DESENVOLVIMENTO ASIÁTICO. Guidebook on Public-Private Partnership in Hospital Management. Available on: <http://www.adb.org/sites/default/files/pub/2013/pppguidebook-hospital-management.pdf>. Accessed on 20 jul. 2020.

BANDEIRA DE MELLO, C. A. (2008). Curso de Direito Administrativo. 25. ed. São Paulo: Malheiros.

BARROS, P. P.; GIRALT, X. M. Contractual Design and PPPs for hospitals: lessons for the Portuguese model. European Journal of Health Economics, v. 10, p. 437-453, 2009.

BENNETT, J.; IOSSA, E. Building and managing facilities for public services. Journal of Public Economics, v. 90, n. 10-11, p. 2143-2160, 2006.

BENTZ, A.; GROUT, P. A.; HALONEN, M. What Should the State Buy? Working paper. Centre for Market and Public Organisation (CMPO), 2001.

BETTIGNIES, J. E; ROSS, T. W. The Economics of Public-private partnerships. Canadian Public Policy, v. 30, p. 135-174, 2004.

BRASIL. Constituição (1988). Emenda Constitucional n 95, de 15 de dezembro de 2016. Altera o Ato das Disposições Constitucionais Transitórias, para instituir o Novo Regime Fiscal, e dá outras providências. Available on <https://legis.senado.leg.br/norma/540698/publicacao/15655553>. Accessed on 08/14/2020.

Lei $n^{\circ}$ 8.987, de 13 de fevereiro de 1995. Dispõe sobre o regime de concessão e permissão da prestação de serviços públicos previsto no art. 175 da Constituição Federal, e dá outras providências. Available on <http://www.planalto.gov.br/ccivil 03/leis/l8987cons.htm>. Accessed on 08/16/2020.

Lei $n^{\circ} 14.035$, de 11 de agosto de 2020. Dispõe sobre procedimentos para a aquisição ou contratação de bens, serviços e insumos destinados ao enfrentamento da emergência de saúde pública de importância internacional decorrente do coronavírus responsável pelo surto de 2019. Available on <http://www.planalto.gov.br/ccivil 03/ Ato2019-2022/2020/Lei/L14035.htm>. Accessed on 08/16/2020. 
Lei $n^{\circ} 11.079$, de 30 de dezembro de 2004. Institui normas gerais para licitação e contratação de parceria público-privada no âmbito da administração pública. Available on $<$ http://www.planalto.gov.br/ccivil 03/ ato2004-2006/2004/lei//11079.htm>. Accessed on $08 / 16 / 2020$.

Decreto $n^{\circ} 5.385$ de 4 de março de 2005. Institui o Comitê Gestor de Parceria Público Privada Federal (CGP), e dá outras providências. Available on $<$ http://www.planalto.gov.br/ccivil 03/ ato2004-2006/2005/Decreto/D5385.htm>. Accessed on 08/16/2020.

. Decreto $n^{\circ} 9.784$ de 7 de maio de 2019. Declara a revogação, para fins do disposto no art. 16 da Lei Complementar $n^{\circ}$ 95, de 26 de fevereiro de 1998, e no art. $9^{\circ}$ do Decreto $n^{\circ}$ 9.759, de 11 de abril de 2019, de decretos normativos. Available on <http://www.planalto.gov.br/ccivil 03/ Ato2019-2022/2019/Decreto/D9784.htm>. Accessed on 08/16/2020.

BRON, B; DIETRICH, A.; MULLER, G. Do lockdowns work? A counterfactual for Sweden. London, Centre for Economic Policy Research, 2020. Available on:

$<$ https://cepr.org/active/publications/discussion_papers/dp.php?dpno=14744>. Accessed on: $2 / 7 / 2020$.

BROWN, S. Global Public-Private Partnerships for Pharmaceuticals: Operational and Normative Features, Challenges, and Prospects. Canadian Public Administration Journal (2008).

BUSO, M.; MARTY, F.; PHUONG, T. T. Public-Private Partnerships from budget constraints: Looking for debt hiding? International Journal of Industrial Organization, v. 51, p. 56-84, 2017.

CAMPOS, K. DE P.; NORMAN, C. D.; JADAD, A. R. Product Development Public-private Partnerships for Public Health: A Systematic Review Using Qualitative Data. Social Science \& Medicine, v. 73, p. 986-994, 2011.

DAVE, D.M.; FRIEDSON, A.I.; MATSUZAWA, K.; YOU KNOW, J.J. When Do Shelter-inPlace Orders Fight COVID-19 Best? Policy Heterogeneity Across States and Adoption Time. Working Paper, National Bureau of Economic Research, 2020.

DI PORTO, E.; NATICCHIONI, P.; VINCENZO SCUTINIO, V. Partial Lockdown and the Spread of COVID-19: Lessons from the Italian Case | IZA - Institute of Labor Economics. Available on: $<$ https://www.iza.org/publications/dp/13375/partial-lockdown-and-the-spread-ofcovid-19-lessonsfrom-the-italian-case $>$. Accessed on: 2/7/2020.

EICHEINBAUM, M. S.; REBELO, S.; TRABANDT, M. The Macroeconomics of Epidemics. Working Paper, National Bureau of Economic Research, 2020.

ENGEL, E., FISHER, R. \& GALETOVIC, A. Soft budgets and renegotiations in publicprivate partnerships. Working Paper. National Bureau of Economic Research, 2009. 
ENGEL, E.; FISCHER, R.; GALETOVIC, A. The Basic Public Finance of Public Private Partnerships. Journal of the European Economic Association, v. 11, n. 1, p. 83- 111, 2013.

EUROPEAN PPP REPORT 2009. Available on < http://www.eib.org/epec/resources/dlaeuropean-ppp-report-2009.pdf>. Accessed on: 02 de ago. 2020.

FAKHOURY, I. N. How the World Bank is looking at COVID-19 and public-private partnerships, right now and post-crisis. World Bank, 2020. Available on < https://blogs.worldbank.org/ppps/howworld-bank-looking-covid-19-and-public-private-partnerships-right-now-and-post-crisis>.

Accessed on 08/16/2020.

FANG, H.; WANG, L.; YANG, Y. Human Mobility Restrictions and the Spread of the Novel Coronavirus (2019-nCoV) in China. Working Paper, National Bureau of Economic Research, 2020.

FARBOODI, M.; JAROSCH, G.; SHIMER, R. Internal and External Effects of Social Distancing in a Pandemic. SSRN Scholarly Paper, Rochester, NY: Social Science Research Network, 2020

FERNANDEZ, R. N.; CARRARO, A.; BALBINOTTO NETO, G.; SILVA, R. V.. Uma Abordagem de Law \& Economics para as Parcerias Público-Privadas no Brasil. Economic Analysis of Law Review, v. 5, p. 205-219, 2014.

FOLHA INFORMATIVA - COVID-19 (DOENÇA CAUSADA PELO NOVO CORONAVÍRUS). Organização Pan-Americana da Saúde. Available on $<$ https://www.paho.org/bra/index.php?option=com content\&view=article\&id=6101:covid19\&ltemi $\underline{d=875}>$. Accessed on 06/15/2020.

FONG, M. W.; GAO, H.; WONG, J. Y.; Xiao, J.; Shiu, E. Y. C; Ryu, S.; Cowling, B. J. Nonpharmaceutical Measures for Pandemic Influenza in Nonhealthcare Settings-Social Distancing Measures. Emerging Infectious Diseases Journal, v. 26, n. 5, 2020.

FRIEDSON, A.; MCNICHOLS, D.; SABIA, J.; DAVE, D. Did California's Shelter-in-Place Order Work? Early Coronavirus-Related Public Health Effects. SSRN Scholarly Paper, Rochester, NY: Social Science Research Network, 2020.

GRIMSEY, D.; LEWIS, M. K. Public Private Partnerships: The Worldwide Revolution in Infrastructure Provision and Project Finance. Edward Elgar Publishing Ltd, Cheltenham, 2004.

GUPTA, S.; NGUYEN, T. D.; ROJAS, F. L.; et al. Tracking Public and Private Responses to the COVID-19 Epidemic: Evidence from State and Local Government Actions. Working Paper, National Bureau of Economic Research, 2020 
HART, O.; SCHLEIFER, A; VISHNY, R. The proper scope of government: theory and applications to prisons. Quarterly Journal of Economics, v. 112, n. 4, p. 1127-1161, 1997.

HART, O. Incomplete Contracts and Public Ownership Remarks and An Application to PublicPrivate Partnerships. Economic Journal, v. 119, p. 69-76, 2003.

HOLMSTROM, B.; MILGROM, P. Multitask Principal-Agent Analyses: Incentive Contracts, Asset Ownership, and Job Design. Journal of Law, Economics and Organization, v. 7, p. 24-52, 1991.

IOSSA E.; MARTIMORT, D. The Simple Micro-Economics of Public-Private Partnerships, Department of Economics and Finance Working Paper n. 09-03, p. 1-56, 2009.

IOSSA, E.; MARTIMORT, D. Risk Allocation and the Costs and Benefits of Public-Private Partnerships. The Rand Journal of Economics, v. 43, n. 3, p. 442-474, 2012.

IOSSA, E; SAUSSIER, S. Public Private Partnerships in Europe for Building and Managing Public Infrastructures: An Economic Perspective. Annals of Public and Cooperative Economics, v. 84, n. 1, p. 25-48, 2018.

KYLE, M. K.; MCGAHAN, A. M. Investments in Pharmaceuticals Before and After Trips. The Review of Economics and Statistics, MIT Press, v. 94, n. 4, p. 1157-1172, 2012.

LA FORGIA, G.; HARDING, A. Public-Private Partnerships and Public Hospital Performance in São Paulo, Brazil. Health Affairs, n. 28, p. 1114-1126, 2009.

MARTIMORT, D.; POUYET, J. To Build or Not to Build: Normative and Positive Theories of, Private-Public Partnerships. International Journal of Industrial Organization, v. 26, p. 393-411, 2008.

MASKIN, E.; TIROLE, J. Public-Private Partnerships and Government Spending Limits. International Journal of Industrial Organization, n. 26, p. 412-420, 2008.

MCKEE, M; EDWARDS, N. ATUN, R. Public-private partnerships for hospitals. Bulletin of the World Health Organization, v. 84, n. 11, p. 890-896, 2006.

MORAES, M. S.; REYES, G. T. Os impactos fiscais dos contratos de parceria público-privada: Estudo de caso do ambiente institucional e da prática no brasil. Banco Interamericano de Desenvolvimento, Nota Técnica № 12-46, 2017.

NÓBREGA, Marcos Antônio Rios da. Parcerias Público-Privadas - Licitação, LRF e Restrições Fiscais. Revista Fórum de Direito Financeiro e Econômico, v. 1, p. 71-91, 2012. 
OLIVEIRA, C. Does "Staying at Home" Save Lives? An Estimation of the Impacts of Social Isolation in the Registered Cases and Deaths by COVID-19 in Brazil. SSRN Scholarly Paper, Rochester, NY: Social Science Research Network, 2020.

OLIVEIRA, C; PEREIRA, R. M.; COSTEIRA, G. M. Avaliando os custos e benefícios da intensificação do isolamento social no Rio Grande do Sul a partir de um experimento natural. Available on: https://www.researchgate.net/publication/342666325_Avaliando_os_custos_e_beneficios_da_in tensificacao_do_isolamento_social_no_Rio_Grande_do_Sul_a_partir_de_um_experimento_nat ural >. Accessed on: 17/07/2020.

NOSE, M. Enforcing Public-Private Partnership Contract: How do Fiscal Institutions Matter? IMF Working Paper, 2017.

NWAKA, S.; RIDLEY, R.G. Virtual drug discovery and development for neglected diseases through public-private partnerships. Nature Reviews, v. 2, p. 919-928, 2003.

TAYLOR, R.; BLAIR, S. Public Hospitals - Options for Reform through Public-Private Partnerships. The World Bank Group Private Sector and Infrastructure Network Washington, p. 14, 2002.

VRUEH, R. L. A. DE; CROMMELIN, D. J. A.; Reflections on the Future of Pharmaceutical PublicPrivate Partnerships: From Input to Impact. Pharmaceutical Research, v. 34, n. 5, 2017.

WHEELER, C.; BERKLEY, S. Initial Lessons from Public-Private Partnerships In Drug and Vaccine Development. Bulletin of the World Health Organization, v. 79, n. 8, p. 728-734, 2001.

\section{Jean Marcel Del Ponte Duarte}

https://orcid.org/0000-0002-8233-0921

PhD student in Applied Economics at the Graduate Program in Organizations and Markets at the Federal University of Pelotas (PPGOM/UFPEL). Master's degree in Applied Economics at the same university and program.

E-mail: jeanmarcel.au@gmail.com

\section{Rodrigo Nobre Fernandez}

https://orcid.org/0000-0001-8596-2898

Doctor in Applied Economics at the Federal University of Rio Grande do Sul (PPGE/UFRGS).

Professor at the Federal University of Pelotas (UFPEL).

E-mail: rodrigonobrefernandez@gmail.com

\section{Rodrigo Vaz Silva}

https://orcid.org/0000-0002-5601-1652 
Master's degree in Criminal Sciences at the Pontifical Catholic University of Rio Grande do Sul (PUC-RS). Professor at the University of Contestado. Federal Highway Police Officer.

E-mail: rodrigovazsilva@gmail.com 